\title{
PARECER
}

\section{Contrato de edição.}

\author{
Antonio Chaves \\ Catedrático de Direito Civil da Faculdade de \\ Direito da USP. Membro da Comissão Revi- \\ sora do Anteprojeto de Cбdigo de Direito de \\ Autor $\Theta$ Direitos Conexos $\Theta$ da Comissão \\ Jurídica e de Legislação da "Confederation \\ Internationale des Sociétés d'Auteurs et \\ Compositeurs".
}

\section{Histórico}

S.P.M. assumiu perante I.B.E.P. o compromisso de escrever livros de matemática, destinados às quatro séries do curso ginasial, em conformidade com o programa oficial.

Dentre as cláusulas usuais, foram consignadas três que merecem realce:

a) pela $10 .^{\mathrm{a}}$ ficou proibido o autor de dispor da obra enquanto vigorar o contrato, sem prévio consentimento do editor, a quem daria prioridade nas mesmas condições;

b) pela 17.a, o autor só poderia denunciar o contrato comunicando, por escrito, ao editor, sua intenção, ocasião em que caberia a êste o direito a mais duas edições, cujos exemplares ostentariam obrigatòriamente, além da numeração, a rubrica do autor;

c) pela $12 .^{a}$ o editor assumiu a obrigação de prestar contas de seis em seis meses.

Nos expressos têrmos dêsses preceitos, S.P.N., em data de 10 de novembro de 1968 dirigiu ao editor uma 
carta, devidamente recebida, rescindindo o contrato e frizando que o período da carência nêle prevista iria permitir ao autor uma adaptação do conteúdo dos livros ao momento atual, e, ao futuro editor, uma reformulação da apresentação gráfica.

Não tendo obtido qualquer resposta, depois de dez meses, notificou extrajudicialmente o editor reiterando os têrmos da carta que havia consumado a resolução, e, sem negar o direito do editor a publicar mais duas edições da obra, exigia a numeração e assinatura dos exemplares, bem como prestação de contas.

Deixava explícito, ao mesmo tempo, que, tendo sido feitas as publicações que integram a edição referente ao ano escolar de 1969, restava ao editor o direito apenas a mais uma, dos livros a serem comercializados no ano escolar seguinte, cujo número de exemplares recomendava fôsse rigorosamente fixado com base na experiência pretérita, para serem vendidos normalmente até junho de $\mathbf{1 9 7 0}$, não ultrapassando o conjunto a cota de 150.000. Esse número, somado a aproximadamente 45.000 publicados e não vendidos, existentes no estoque da editora, perfaz o montante de 195.000, suficiente para atender à demanda do mercado escolar do referido ano.

A partir de julho de 1970 iria incrementar a divulgação de novos textos destinados a substituir os anteriores, como resultado da utilização de técnica didática e de composição tipográfica mais atualizadas.

Também a segunda interpelação não mereceu qualquer resposta. Não teve dúvidas então S.N.P. em procurar outra editora, com a qual, em data de 12 de setembro de 1969 celebrou novo ajuste.

Formula a segunda editora a seguinte 


\section{Consulta}

$\left.1 .^{\circ}\right)$ A carta de 10 de novembro de 1968 e a notificação extra-judicial são bastante explícitas para sustar a execução do primeiro contrato, a partir do segundo semestre de 1970 ?

2. ) E válida a segunda convenção? No caso afirmativo, é possível a publicação dos livros? Até que ponto êste acôrdo pode ser atingido ou prejudicado pelo anterior?

$3^{\circ}{ }^{\circ}$ Quais as conseqüências que poderão advir do fato do primeiro editor ultrapassar, eventualmente, a tiragem estipulada na notificação?

4. $\left.{ }^{\circ}\right)$ Terá êle direito a busca e apreensão dos volumes que forem editados pelo segundo, em virtude do novo contrato? Poderá obrigar êste a comprar o estoque remanescente de sua última edição?

$5^{\circ} .^{\circ}$ Existe alguma outra medida específica para garantir a segunda editora contra qualquer providência possivelmente maliciosa do antigo editor?

\section{PARecer}

\section{Considerações preliminares} cláusula

O ponto fundamental da controvérsia encontra-se na

"10 - Fica proibido ao autor dispor da obra em seu todo ou em parte, enquanto viger o contrato, sem prévio consentimento do editor e da natureza específica e da mesma forma dará prioridade a qualquer outra obra sua, nas mesmas condições que lhe ofereça qualquer editor".

Pareceria, à primeira vista, que, não tendo conseguido o prévio consentimento do editor, não poderia o autor, 
como fêz, ceder a um segundo empresário os seus direitos autorais.

Mas a proibição encontra imediata e lógica restrição numa condição suspensiva explícita: "enquanto viger o contrato", tornando perfeitamente claro que, assim que deixar êle de viger, cessará a proibição.

$\mathrm{E}$ quando termina o tempo durante o qual está destinado a vigorar o ajuste?

Tâo logo seja êle denunciado, como se verifica pela cláusula subordinada à epígrafe: "DA RESILIÇÃo DO CONTRATO DE EDIÇÃ̄o".

“17. 0 autor só poderá denunciar o presente contrato de edição, comunicando, por escrito, ao editor sua intenção e quando caberá a êste o direito a mais duas edições da obra em tôdas as suas séries. Nêste caso, as edições terão obrigatòriamente, além da numeração, a rubrica do autor."

Apesar da redação aparentemente restritiva, percebese, de imediato, que abre, às escâncaras, a port́a ao autor para que saia do acôrdo, exigindo apenas o preenchimento de duas condições: 1. ${ }^{\text {a }}$ ) comunicação, por escrito, dessa intenção ao editor; $2^{\text {a }}$ ) direito, a êste reconhecido, a mais duas edições da obra em tôdas as suas séries.

Tanto é essa cláusula mais favorável ao autor do que ao editor, que, além de admitir êsse direito de maneira tão explícita, ainda o reforça com uma imposição que, embora destinada a ressalvar a honorabilidade do empresário, resguarda os interêsses do autor: a da dupla obrigatoriedade da numeração e rubrica do autor em cada um dos exemplares.

Esse intróito torna mais fácil a colocação dos problemas, fazendo brotar, com tôda espontaneidade, as soluções correspondentes. 


\section{A rescisão do primeiro contrato}

A carta de 10 de novembro de 1968 não susta apenas a continuidade do primeiro ajuste; tem um alcance muito mais amplo: rescinde-o, por completo, admitindo apenas, como efeito remanescente, residual, o direito do editor a mais duas edições, nos têrmos da segunda parte da cláusula $17 .^{\mathrm{a}}$.

A continuidade da vigência do contrato estava subordinada, já se viu, à condição da não ocorrência de sua denúncia, mediante comunicação por escrito ao editor.

É o que resulta dos seus próprios têrmos, em perfeita harmonia com o disposto no art. 119 do Código Civil: "Se fôr resolutiva a condição, enquanto esta se não realizar, vigorará $o$ ato jurídico, podendo exercer-se desde o momento por êle estabelecido; mas, verificada a condição, para todos os efeitos, se extingue o direito a que ela se opõe."

Acrescenta o parágrafo único distinção de importância fundamental: "A condição resolutiva da obrigação pode ser expressa, ou tácita; operando, no primeiro caso, de pleno direito, e por interpelação judicial, no segundo."

A cláusula $17 .{ }^{a}$ contém uma condição resolutiva expressa, porque claramente enunciada: a do autor poder denunciar o contrato, comunicando, por escrito, a sua intenção.

Perfeitamente dispensável, nestas condições, a interpelação judicial.

O autor fêz mesmo mais do que lhe cumpria: tendo comunicado, por escrito, a sua intenção, ainda a reiterou através da notificação extra-judicial, mera superfetação, no caso, pois a exigência estava satisfeita, o contrato, rescindido.

Não existe divergência a êsse propósito. 
Orlando Gomes, Contratos, Forense, Rio, 1959, p. 202 ressalta que a faculdade de pedir a resolução do contrato pode decorrer de estipulação ou de presunção legal. Acordes as partes em que possa ser exercida, haverá pacto comissório expresso, não sendo necessário que a resolução se dê por sentença judicial.

"Havendo pacto comissório expresso, o contrato se resolve de pleno direito. Quando muito o juiz, em caso de contestação, constata a resolução. Não lhe compete pronunciá-lo, como procede quando a cláusula resolutiva é implícita."

Darcy Bessone de Oliveira Andrade, Do Contrato, Forense, Rio, 1960, p. 325, realça, por sua vez, usando expressões análogas, que a declaração de resolver-se o contrato de pleno direito exprime a dispensa de prévia decisão jurisdicional a respeito de sua ocorrência. Não impossibilita a apreciação do fato $a$ posteriori pela Justiça, inclusive porque pode esta considerar improcedente a argüição de inadimplemento :

"Apenas significa que o prejudicado pode, de plano, considerar-se desvinculado, sem ter de recorrer prèviamente ao Judiciário para obter a resolução do contrato."

Orosimbo Nonato, Curso de Obrigações, Forense, Rio, 1960, Parte II, v. I, p. 320 acrescenta que

“A interpelação pode ser judicial ou extra-judicial, por escrito ou verbal. Ponto é se lhe prove a existência, e o conteúdo, e seja efetuada em tempo hábil. .

"A interpelação pode ser verbal, nas condições acima expostas, uma vez ministre o credor a prova de sua ocorrência e conteúdo. E o que passa, em face do ius quod est, nas relações de ordem civil." 
Eduardo Espínola, no verbete "Condição", que escreveu para o Dicionário Enciclopédico do Direito Brasileiro, Konfino, Rio, s/d, v. 10, assevera, com base nos ensinamentos de Savigny, Waechter, Vangerow e Windscheid, ficar "fora de qualquer dúvida" a dispensa da intervenção da justiça para pronunciar a resolução.

Para encerrar as citações, que muito longe ainda poderiam ser levadas: Agostinho Alvim, "Da Inexecução das Obrigações e suas Conseqüências", Jurídica e Universitária, Rio, 3. ${ }^{\mathrm{a}}$ ed., 1965 , comentando à pág. 130 o art. $960.2 .^{\mathrm{a}}$ alínea do Código Civil, de acôrdo com a qual não havendo prazo assinado, começa a mora desde a interpelação, notificação ou protesto, acentua: não pode terminar um prazo que não começou. "Não havendo prazo assinado, o remédio do credor está na interpelação, notificação ou protesto", cujo denominador comum é a cientificação do devedor.

"Admite-se, porém, a cientificação extra-judicial, quando se assenta em convenção, o que é razoável, porque a matéria não é de ordem pública e as partes podem discipliná-la diferentemente."

Lapidar, finalmente, a proposição contida no Projeto de Código de Obrigações de 1965:

“Art. 337. A resilição unilateral, aos casos em que a lei o não vede, opera mediante denúncia notificada à outra parte."

Nem se diga que, por essa forma estaremos admitindo que a vontade unilateral é suficiente para pôr fim ao contrato.

Abordando exatamente êsse ponto, obtempera DARCY Bessone de Olineira Andrade, na monografia citada, pág. 323 , que, em princípio, a vontade unilateral sòmente dissolve o contrato quando a lei outorga êsse poder, como 
ocorre nos contratos de mandato, de hospedagem, de serviços domésticos.

"Mas, em geral" - adita logo em seguida — "nos contratos por tempo indeterminado, e de execução continuada, qualquer dos contratantes pode unilateralmente desvincular-se, dissolvendo-os. A indeterminação do tempo de duração do contrato ocasionaria a permanência infinita do vínculo, se não fôsse facultado a qualquer das partes, através do ius poenitendi, desligar-se, quando lhe aprouvesse.

"Assiste, assim, a cada um dos contratantes o direito potestativo de desvincular-se."

\section{Validade do segundo contrato}

Nâo apresenta, assim, qualquer embaraço a análise do ajuste ulterior, à luz dos dispositivos legais reguladores da matéria.

É certo que, nos têrmos do art. 1.349 do Código Civil, "Enquanto não. se esgotarem as edições a que tiver direito o editor, não poderá o autor dispor da obra no todo ou em parte."

Mas o próprio autor teve o cuidado de ressalvar, na cláusula 17. ${ }^{\mathrm{a}}$, na notificação de 10 de novembro de 1968, e, com maior clareza ainda, na de 9 de setembro do ano seguinte, o direito do editor a outras duas edições, uma para cada ano escolar de 1969 e de 1970, num total calculado, incluindo em volumes publicados e não vendidos, de 195.000 unidades.

Ainda que o empresário pretendesse rebelar-se contra aquilo que êle mesmo assinou, procurando inculcar a inexistência de um acôrdo insofismável, não há como desconhecer que o autor ressalvou plenamente, por essa forma, os interêsses de seu primeiro co-contratante. 
Harmonizou, por essa forma, sua conduta com o disposto no art. 1.351 do aludido Estatuto: "No caso de nova edição ou tiragem, não havendo acôrdo entre as partes contratantes sôbre a maneira de exercerem seus direitos, poderá qualquer delas rescindir o contrato, sem prejuizo da edição anterior."

A ausência de qualquer resposta às interpelações do autor ratificaram a sua liberdade do anterior compromisso.

A não ser assim teríamos, não um contrato de edição, mas uma verdadeira cessão de direitos autorais, o que não só não é de se presumir, mas contraria as próprias cláusulas estipuladas.

Já em 1893 advertia Gustave Lardeur, "Du Contrat d'Edition en Matière Littéraire", Rousseau, Paris, p. 153:

“. . na dúvida a presunção será em favor do simples contrato de edição e não da venda da propriedade literária."

Também J. Labaurie, "L'Usurpation en Matière Littéraire et Artistique", Boccard, Paris, 1919, recomenda, à p. 48, que a autorização do autor seja interpretada como valendo, seja qual fôr a forma em que tenha sido dada, sem deixar lugar a qualquer fato de usurpação que possa ser reprimido pela lei, e, à pág. 49 , que o juiz não decida contra o autor a não ser com a maior circunspecção: " $O$ abandono de um direito não se deve presumir fàcilmente."

Voltando sua atenção para o problema das edições sucessivas salienta LARDEur, op. cit., pág. 177 que, cedendo ao editor um número ilimitado de edições, de uma vez, o autor interditaria a si mesmo modificar a obra contra a vontade do editor, e perderia o direito de se opor a uma nova edição.

"Parece-nos que semelhante intenção, por parte do autor, não poderia ser presumida, em principio, e que, na dúvida, o contrato não deva comportar senão uma edição." 
Alfredo De Gregonio, em seu completo "Il Contratto di Edizione", Athenaeum, Roma, 1913, define, com critério rigoroso, quais os direitos alienados pelo autor e quais os que continuam permanecendo em seu poder:

'restano nell' autore le facoltà non contenute nel diritto di edizione da lui alienato, o non altrimenti trasmesse, mediante una specifica determiminazione contrattuale, all'editore."

Em nada interfere o segundo contrato com a obrigação que tem o primitivo editor de continuar vendendo, ao preço normal, os exemplares que permaneceram em estoque, "sem que essa faculdade reconhecida ao primeiro editor", - para usar textualmente as palavras da última alínea do art. 56 da lei francesa n. 57-298, de 11 de março de 1957, reconhecidamente a mais perfeita e completa em matéria de contrato de edição, - "impeça ao autor de mandar proceder a uma nova edição..."

$O$ contrato deixa de ter vigência com relação às edições sucessivas, mas continua plenamente em vigor até esgotar a sua finalidade. Por isso mesmo toma o cuidado de aditar a mesma lei :

“Art. 57. O editor é obrigado a garantir à obra uma exploração permanente e seguida e uma distribuição comercial na conformidade dos usos da profissão."

\section{Efeitos remanescentes de um contrato rescindido}

A questão que apresenta o terceiro quesito é mais complexa do que dêle parece resultar.

Antes de verificarmos as possiveis conseqüências da eventualidade de ultrapassar o primeiro editor a tiragem indicada na notificação, será de tôda conveniência averiguarmos se êle tem o direito de prorrogar indefinidamente 
a publicação das duas edições a que alude a cláusula 17. ${ }^{\mathrm{a}}$ do contrato.

Bem se compreende a importância de que se reveste o fato de que as publicações remanescentes, a que tem direito o primeiro editor, sejam promovidas em tempo oportuno, isto é, seguindo a praxe já estabelecida nos anos anteriores, de modo a permitir o seu natural escoamento até o mês de julho de 1970 .

Do contrário estaríamos outorgando ao editor um arbítrio inadmissível, em prejuízo do autor, permitindo que interfira diretamente sôbre a infiltração das novas tiragens a que já não tem mais qualquer direito. Aliás, diga-se de passagem, em prejuízo do próprio empresário, porque ninguém iria procurar os exemplares de uma edição, sabendo que existe outra, mais atualizada, mais moderna.

Bem pertinentes as observações de JeAn Rault, "Le Contrat d'Édition en Droit Français”, Dalloz, Paris, 1927, pág. 279:

"Em princípio, o editor deve conformar-se às condições do contrato, e jamais se recomendaria suficientemente às partes prever expressamente a época em que a obra deve ser publicada. Excessivo número de contratos sofrem, nêsse particular, de uma imprecisão lamentável."

Indaga qual o critério para determinar o prazo além do qual o editor será considerado como tendo violado as suas obrigações, e consigna:

"On ne saurait en effet reconnaitre à l'éditeur le droit de retarder indéfiniment la publication de l'ouvrage, sous prétexte qu'aucun délai n'a été stipulé au contrat. Les conventions doivent êfre exécutées de bonne foi. L'on ne saurait en conséquence permettre à l'éditeur de se soustraire par ce moyen détourné à l'obligation de publier qui lui incombe. L'obligation de publier rentre selon nous 
dans la catégorie des obligations visées par l'article 1.146 du code civil, obligations que ne peuvent être exécutées que pendant un certain temps."

Nas cinco páginas que dedica ao assunto encarece que a razão pela qual se deve obrigar o editor à publicação imediata consiste na circunstância de que, como regra geral, um livro, uma vez terminado e remetido ao editor, não perde nenhuma de suas qualidades se fôr imediatamente publicado. "Ao contrário os retardamentos aduzidos ao lançamento da obra não podem ser senão a ela prejudiciais e em certos casos chegam mesmo a retirar-lhe todo interêsse."

O público não perdôa ao autor - acrescenta - publicar uma obra que no dia em que fôr posta à venda não ofereça senão o valor de um documento histórico.

"De toute manière, le retard apporté à la publication constitue une atteinte au droit moral de l'auteur."

Aponta, então, duas dentre as várias sanções possíveis:

a) reclamar perdas e danos equivalentes ao prejuízo sofrido;

b) reclamar a resilição do contrato e, conseqüentemente, proibir ao editor publicar a obra cedida.

Podem os tribunais ainda, conclue, autorizar a publicação, com a cominação da inserção de uma nota apontando a data da composição ou outras indicações suscetíveis de justificar ou explicar a atitude do autor ou a posição por êle assumida.

LARDEur, por sua vez, abordando a pág. 163 o problema do prazo dentro do qual deve ser feita a publicação preleciona: "Se o contrato fôr mudo a êsse respeito, a impressão deve ser iniciada logo e continuada sem demora. Eis aí uma questão de fato, cuja apreciação é entregue aos tribunais." 
É no entanto na mencionada preciosa obra de Alfredo DE Ǵregorio que iremos, mais uma vez, colhêr os elementos necessários para espancar qualquer dúvida renitente.

Ressalta o professor de Messina o inconveniente da falta de uma disposição legal fixando, no silêncio das partes, o número das cópias de que se deva entender composta cada ediçãu, pois os editores ver-se-iam obrigados a declarar, vez por vez, o seu número, sempre que tivesse de ser diferente do fixado pela mencionada norma. A omissão da indicação - agrega - deve ser considerada como caso de indeterminação, embora parcial, do conteúdo da alienação do direito do autor.

Menos usada do que a indicação do número de cópias que poderão ser tiradas pelo editor, para fixar os limites dentro dos quais deverão manter-se as faculdades do editor, é a indicação da duração do direito de edição que lhe é concedido, justamente o caso que nos interessa.

“De fato êste sistema pode fàcilmente dar lugar a não leves dificuldades no momento em que, expirado o têrmo da mencionada duração, dever-se-ão regular as relações entre editor e autor, principalmente com referência às cópias que ainda permaneçam junto ao editor e junto aos livreiros. Certamente a solução das mesmas constitue fundamentalmente uma questão de interpretação da vontade contratual; mas parece-me razoável presumir - em falta de uma clara disposição contrária - que as partes contraentes não tenham tido a intenção de atribuir ao editor, durante um certo período, a faculdade de fazer tiragens da obra, mas sòmente de limitar a faculdade de aproveitamento que lhe foi concedida, ao número das cópias que êle conseguirá colocar dentro dêsse mesmo período." 
Acentua a diferença fundamental entre as duas eventualidades: na primeira o editor poderia, dentro do prazo fixado, jmprimir o número de cópias que mais lhe aprouvesse e colocá-las em vantagem própria, mesmo depois. Na segunda, ao contrário, também esta última faculdade viria a faltar com o vencer-se do prazo.

"Ora, per respingere la prima ipotesi, basta pensare che con questa si permetterebbe all'editore di prolungare indefinitamente lo sfruttamento dell'opera, sol che egli volesse sopportare il rischio d'una tiratura sovrabbondante: e ciò accadrebbe proprio per le opere coronate di miglior successo."

Nota que se se abandonou o sistema comum, é presumível que a intenção tenha sido de estabelecer com segurança o momento a partir do qual o autor voltará ao pleno gôzo da sua obra, e não para conservar o inconveniente do próprio sistema - a respeito dêsse momento - agravando-o ainda com o perigo de ir ao encontro de contestações.

E conclue, incisivamente:

"De modo que acredito que quando se tenha estabelecido no contrato a duração do direito de edição, deva-se considerar - ressalvada bem entendido a prova de uma diferente vontade dos contraentes - que vencido o têrmo da mesma o benefício que poderá retirar-se das cópias ainda não vendidas, deduzidas as despesas proporcionalmente mantidas por elas pelo editor, revertam em vantagem do autor."

Nem poderão ser olvidadas as advertências de JEAN Rault, a pág. 126 de sua obra citada: a determinação da natureza de uma obrigação contratual depende ùnicamente das circunstâncias: é soberanamente efetuada pelos juízes.

“É a intenção comum das partes que determina a natureza de suas relações jurídicas. A pesquisa da intenção, a investigação psicológica implicam por definição 
mesmo uma liberdade de julgamento incompativel com tòda qualificação prévia."

A aludida lei francêsa n. 57-298, de 1957, dando a solução que não é senão a que se deduz da lição dos tratadistas, dispõe no art. 56, alíneas 4 e 5 :

"A défaut de convention spéciale, l'éditeur doit réaliser l'édition dans un délai fixé par les usages de la profession.

En cas de contrat à durée déterminée, les droits du cessionnaire s'éteignent de plein droit à l'expiration du délai, sans qu'il soit besoin de mise en demeure."

\section{Responsabilidade pós-contratual Consequências de uma possível contrafação}

As características do primeiro contrato, sem embargo de sua indeterminação, dão margem a que seja fixado de ano em ano o número de exemplares, como aliás fêz o autor, indicando, na segunda notificação, o máximo a que o editor teria direito.

Por hesitante que possa parecer e interpretação do silêncio como manifestação da vontade contratual, não há como duvidar, no caso, que a atitude passiva do editor confirma plenamente o brocardo popular segundo o qual quem cala consente: do contrário deveria, de imediato, manifestar sua divergência, e apontar o número de exemplares a que se julgasse com direito.

Não houve contra-notificação, não houve protesto, não houve, sequer, uma resposta genèricamente negativa: está assim fixado, naquele montante de 195.000 exemplares, aliás respeitável, o máximo admissivel.

Vejamos agora quais as conseqüências de querer ultrapassar o primeiro editor essa tiragem. 
Comprovado, pela experiência pretérita, que o mercado não está em condições de absorver maior número de exemplares, verificado que não foi superior a tiragem dos anos imediatamente anteriores, manifestada, pelo autor, a intenção de introduzir aperfeiçoamentos no seu trabalho, irá, sem dúvida, o bom senso e o tirocínio profissional do próprio editor aconselhá-lo, a bem do seu interêsse, a não avcnturar-se numa publicação que corra o perigo de não resultar completamente absorvida no periodo escolar.

Mas se, por um despique que só se admite para argumentar, pretendesse exceder o limite da tiragem estipulado na notificação, não resta dúvida que estaria cometendo um crime, sob o ponto de vista penal, e um ilícito, sob o ponto de vista civil.

Nos têrmos do art. 184 do Código Penal, contrafação é a violação de direito do autor de obra literária, científica ou artística, à qual, é cominada a pena de detenção de três meses a um ano, ou multa de um a cinco cruzeiros novos, acrescentando o parágrafo único que na mesma pena incorre quem vende ou expõe à venda, adquire, oculta ou tem em depósito, para o fim de venda, obra literária, científica ou artística, produzida com violação do direito autoral.

Dentre os vários dispositivos referentes à matéria, do Código Civil, das Convenções internacionais, e da legislação complementar, há que considerar o art. 689 daquele Estatuto, na parte que diz respeito à reprodução de obra em vias de publicação sem outorga ou aquiescência do autor.

As conseqüências aí apontadas serão a perda, em benefício do autor, dos exemplares da reprodução fraudulenta, que se apreenderem, e o pagamento do valor de tôda a edição, mesmo êsses exemplares, ao preço por que estiverem à venda os genuínos, ou em que forem avaliados. Não se conhecendo o número de exemplares fraudulenta- 
mente impressos e distribuídos, pagará o transgressor o valor de mil exemplares, além dos apreendidos.

Adita o art. 672 que o autor, cuja obra se reproduzir fraudulentamente, poderá, basta que o saiba, requerer a apreensão dos exemplares reproduzidos, subsistindo-lhe o direito à indenização de perdas e danos, ainda que nenhum exemplar se encontre.

Incidindo diretamente na possibilidade de uma edição sem numeração dos exemplares e sem a assinatura exigidas no caso, considera o decreto n. 4.790 , de 2 de janeiro de 1924 , art. $4 .^{\circ}$, parágrafo único, contrafação, sujeitando o editor ou impressor ao pagamento de perdas e danos, qualquer repetição de número, bem como exemplar sem numeração, ou que apresente numeração excedente da tiragem contratada.

É a hipótese que os tratadistas lembram em primeiro lugar quando cuidam de caracterizar a contrafação.

Assim, Gustave Lardeur, pág. 203, com apôio em abundante jurisprudência:

" $O$ editor comete uma contrafação quando continua a publicação após a expiração dos' prazos que lhe foram concedidos, . . ou quando ultrapassem seu direito relativamente ao número das edições ou dos exemplares... A tolerância do autor não é por outro lado suficiente, em princípio, para legitimar a contrafação. ."

J. Labaurie, em seu citado "L'Usurpation en Matière Littéraire et Artistique”, p. 51:

"O editor cessionário pode, de seu lado, cometer o delito de contrafação. É, por exemplo, o caso do editor que imprime um número de exemplares superior àquele que recebeu a incumbência 
de tirar, ou que procede, sem o consentimento do autor, a uma reimpressão, após ter esgotado o número de edições que lhe foi concedido. Esses exemplares, que permanecerem fora das previsões do autor, constituem reproduções não autorizadas - contrafações. A lei alemã o estipula expressamente. . Mas os princípios gerais são suficientes para estabelecer essa solução."

Depois de duas notificações, estamos diante de algo muito mais grave do que de uma simples infração contratual. O primeiro aviso constitue como que o separador das águas da boa e da má fé. Aquela, se tinha alguma viabilidade de ser invocada antes do aviso, jamais poderia ser admitida depois de advertido o possível infrator da rescisão do contrato.

Qual a importância da distinção?

Compreendeu bem o velho Gustave Lardeur, pgs. 205 e 206:

"A diferenciação entre as sanções civis do contrato e a contrafação apresenta um grande interêsse. A contrafação é um delito, que deve ser perseguido perante os tribunais criminais, e expõe o culpado a penalidades, sem contar as perdas e danos a serem pagos na ordem civil.

“A simples violação do contrato não dá, ao contrário, abertura senão a uma demanda civil.. Além do mais a má fé é um elemento essencial do delito de contrafação, ela é, por outro lado, presumida, e é ao réu que compete provar a sua boa fé. A ação civil, ao contrário, pode ser exercida com sucesso contra o autor ou o editor que não tiver executarlo suas obrigações, tivesse êle a melhor fé do mundo." 
Consequências da violação das obrigações de prełstar contas, de numerar os exemplares e facultar ao autor a rescisão de asinatura

Revela a segunda editora uma preocupação pelo eventual comportamento da primeira, no momento em que passar a obra a ser divulgada na conformidade do novo contrato.

Sem razão, no entanto. Já vimos que o primeiro contrato está rescindido, no que diz respeito à possibilidade de edições posteriores às ressalvadas na cláusula 17.a. Mas continua em pleno vigor, até a venda do derradeiro exemplar das tiragens já levadas a efeito.

Para aquilatar a imprudência que cometeria o primeiro empresário, ao procurar prejudicar o segundo e o autor, já no âmbito também pessoal de concorrência desleal, convém ter presente que pelo menos duas violações contratuais gravíssimas já estão perfeitamente caracterizadas. Implicam elas em que, ainda que contrariando a evidência não se quisesse reconhecer a rescisão do contrato de pleno direito, não poderia êle, nos têrmos do art. 1.092 do Código Civil, "caput", antes de cumpridas suas obrigações, exigir o implemento do outro contratante.

A primeira violação diz respeito a cláusula 12. ${ }^{a}$, pela qual o primeiro editor obriga-se a prestar contas ao autor de seis em seis meses, o que, como resulta da notificação, não cumpriu.

Semelhante infração, no dizer de Gustave Lardeur constitue outro crime: o de abuso de confiança. O editor, no que diz respeito à venda dos exemplares, constitue-se em verdadeiro mandatário do autor, e como tal é obrigado a prestar-lhe contas e a remeter-lhe as importâncias devidas (pág. 208).

Tem como complemento a obrigação assumida pelo empresário, na cláusula $14 .^{\mathrm{a}}$, de exibir seus documentos e li- 
vros de escrituração ao autor, para apuração dos seus direitos.

A segunda transgressão diz respeito ao compromisso de numerar os exemplares e de facultar ao autor o direito por êste reclamado sem resultado de apor a sua rubrica nas duas edições remanescentes, tão logo denunciado o contrato.

Terá promovido as edições a que tinha direito? Não terá promovido? Mantendo-se mudo e quêdo, silenciando, mesmo depois de espicaçado duas vêzes, está o editor muito afastado de uma atitude proveitosa.

Longe de beneficiar-se, tôdas as precauções vão se voltando contra êle, principalmente diante da franqueza e da lealdade com que o outro contratante vem se orientando desde seus primeiros passos.

Os contratos - teve oportunidade de ressaltar Pothier fazem-se no interêsse e na utilidade recíproca de cada uma das partes. Não se conceberia, na compreensão moderna da reciprocidade dos direitos e dos deveres, que a malícia de uma das partes pudesse beneficiá-la, contrariando a lei, os usos e os costumes, e o próprio espírito da convenção.

Não tendo sido o autor convocado para rubricar os exemplares, a presunção é de que não tenham sido editados, e se o tiverem sido, mesmo dentro da previsão, ou em número inferior, mas sem numeração e sem rubrica, ou sem uma ou outra, serão exemplares contrafeitos.

Ainda uma vez tem razão Gustave LaRdeur quando assinala, a pág. 175, que sòmente por êsse sistema será possível ao autor saber o número exato dos exemplares vendidos, direito tanto mais justificado porquanto o autor está pecuniàriamente interessado nos benefícios do empreendimento, não podendo o editor furtar-se a permitir seu contrôle e a entregar-lhe, se fôr necessário, a sua contabilidade.

Alfredo de Gregorio, aludindo a êsse meio de fiscalização, consigna, a págs. 275-277 ser bastante difícil que um 
editor, por pouco escrupuloso que seja, chegue ao ponto de falsificar a assinatura do autor.

A iniciativa, aliás, devia ter sido tomada pelo próprio editor.

Se várias edições são previstas no contrato - adverte Valerio de Sanctis, com sua imensa autoridade de renomado especialista, em seu recentíssimo "Contratto di Edizione.", Giuffrè, Milano, 19்65, p. 201 - o editor é obrigado a avisar o autor da época presumível do esgotamento da edição em curso, dentro de um prazo conveniente, antes da própria época, declarando, ao mesmo tempo, se tem ou não intenção de levar a efeito uma nova edição. Do contrário, incorre na eventual resolução do contrato pela não publicação da nova edição, comportando várias conseqüências.

Dentre tôdas, interessa destacar a possibilidade de retirar o autor a obra do comércio.

No item V da segunda notificação, manifestou êle a preocupação louvabilíssima de incorporar em livros de importância tão fundamental para a formação de nossa juventude não sòmente o resultado da utilização de novas técnicas didáticas, como até mesmo de composição gráfica, "modernamente exigidas pela evolução acelerada dos conhecimentos humanos."

À vista dêsses elementos, seria um contra senso vislumbrar-se sequer a possibilidade de conseguir o primeiro editor qualquer apreensão dos volumes a serem editados pelo segundo, em virtude de novo contrato.

É ao autor que se reconhece o direito a essa medida enérgica de busca e apreensão dos volumes que, por não terem sido postos tempestivamente à venda, tornaram-se desatualizados, e, se divulgados, prejudicariam o direito moral do autor.

Tem êle o direito que, na falta de melhor expressão, é denominado de "arrependimento". Salientávamos em nosso Direito Autoral de Radiodifusão, Rev. dos Tribunais, S. Paulo, 1952, p. 321 e segs., que, nos têrmos do art. 1.350 
do Código Civil tem o autor o direito de fazer, nas edições sucessivas de suas obras, as emendas e alterações que lhe aprouverem, ressalvado o direito do empresário de indenizar-se pelos gastos extraordinários.

E transcreviamos a opinião do grande tratadista norteamericano, Stephen P. LAdAs, "The International Protection of Literary and Artistic Property", MacMillan, New York, 1938:

"O direito do autor de retirar sua obra da circulação e de destruí-la pode ser exercido quando sérias razões morais ou pessoais compilam o autor a proceder por essa forma em proteção à sua honorabilidade e reputação, isto é, quando a obra não estiver mais de acôrdo com as convicções morais ou com a sua consciência literária ou artística."

Esse direito de arrependimento, sancionado pelas leis mais completas, como a francesa de 1957 e a italiana de 1942, é plenamente justificado por E. Piola CASELli, "Trattato del Diritto di Autore e del Contratto di Edizione", Marghieri, Napoli, 1927, pág. 848, que observa não poder o editor sequer invocar o contrato:

"O contrato, no momento de sua estipulação, justificava a disposição tomada pelo editor no sentido da publicação da obra, não porque o direito de publicação tivesse sido a êle transferido; mas porque a própria publicação resultava naquele momento em conformidade à vontade do autor. Vindo a faltar esta conformidade, a faculdade do editor cai de jure, porque entre os dois interêsses jurídicos que então vêm a se chocar, ou seja o interêsse do autor de não publicar, baseado numa exigência da sua personalidade e o interêsse patrimonial do editor de publicar, baseado no contrato, aquele deve sem dúvida prevalecer, seja pela sua maior 
nobreza jurídica, seja porque, se o prejuizo econômico que o editor porventura sofra, pode ser eliminado com a prestação dos danos por parte do autor, o prejuízo acarretado à personalidade do próprio autor não pode encontrar uma reparação equivalente."

E por entre uma série de considerações conclue demonstrando que o editor deve dobrar a cabeça frente ̀̀ vontade do autor que, no exercício de que não deve dar satisfação do seu direito pessoal, recuse publicar a obra. Não pode, portanto levar a efeito a publicação que lhe foi proibida, e, se o fizesse, expor-se-ia a uma ação de contrafação.

Não discrepa a lição de VAI,erio de SAnctis, a págs. 261-262 de sua obra citada, consignando, entre as várias hipóteses de extinção do contrato, a decorrente da retirada da obra por parte do seu criador: "O legislador italiano, no contraste entre os dois interêsses jurídicos, o do autor de poder voltar atrás do concedido direito de publicação e de difusão da obra em público, e o do concessionário, de proceder à distribuição comercial dos exemplares da obra, ou de prosseguir na sua distribuição, quis que prevalecesse o do autor, como direito de caráter pessoal e portanto intransmissível, insubrogável, imprescritível e irrenunciável, em condições de alinhar-se ao lado de outros direitos pessoais do autor..."

Uma vez proferida a sentença dever-se-á considerar extinto o contrato de edição,

"in quanto il divieto, da parte del giudice della riproduzione e spaccio dell'opera svuota il contratto del suo oggetto; la prosecuzione della riproduzione e dello spaccio degli esemplari dell' opera diviene, così, illecita e soggetta, come tale, alle sanzioni civili e penali comminate dalla legge (ultimo comme dell'art. 143 1. d. a.)." 


\section{Conclusão}

Chegamos ao remate.

Ao primeiro quesito responderemos que, sem dúvida alguma, a carta e a notificação expedidas pelo autor vão muito além de "sustar" a execução do primeiro contrato a partir do segundo semestre de 1970: a primeira foi, por si só, à vista da redação da cláusula 17 do primeiro contrato, suficiente para ocasionar a rescisão do contrato, sem qualquer prejuízo dos interêsses tanto do autor como do editor.

Parecem inspiradas no exame do caso em tela as palavras que o já tantas vêzes citado Gustave Lardeur expende a pág. 190:

"Os direitos do editor subsistem durante todo o período previsto no contrato, ou durante todo o tempo necessário para escoar o número de edições autorizado. Dispensável encarecer, todavia, que o editor, a quem foram cedidas diversas edições, sem indicação da época em que deveriam ser publicadas, não pode diferir além medida sua publicação, a fim de retardar o momento em que o autor deve retomar seus direitos. Existe aí uma questão de boa fé que o tribunal deverá apreciar. Se, por exemplo, depois de notificado pelo autor, o editor recusar publicar, o tribunal poderá decretar a perda do seu direito.

"Quando findam os direitos do editor, o autor recobra os seus; sòmente êle. daí por diante, pode autorizar a publicação. O editor todavia conserva a faculdade de esgotar livremente os exemplares que permanecem em seus depósitos, desde que êle os tenha legitimamente tirado no limite permitido pelo contrato, e não tenha cometido a êsse propósito abuso de direito." 
Trata-se, aliás, de ressalva que a lei francesa estabelece expressamente na última alínea do art. 56: “L'éditeur pourra toutefois procéder, pendant trois ans après cette expiration, à l'écoulement, au prix normal, des exemplaires restant en stock, à moins que l'auteur ne préfère acheter ces exemplaires moyennant un prix qui sera fixé à dire d'experts à défaut d'accord amiable, sans que cette faculté reconnue au premier éditeur interdise à l'auteur de faire procéder à une nouvelle édition dans un délai de trente mois."

Quanto à segunda questão: rescindido, como está, o segundo ajuste no que diz respeito às edições futuras, cumpridas, por parte do criador da obra, tôdas as exigências contratuais, desvinculado como ficou, depois das duas notificações, de qualquer ulterior obrigação, podia perfeitamente, como fêz, subscrever o segundo contrato, tanto mais que se propõe respeitar religiosamente os direitos remanescentes do empresário.

Não há, nestas condições, possibilidade de que o segundo contrato seja "alcançado" ou "prejudicado" pelo anterior.

Invoquemos ainda uma vez a lição límpida do último tratadista citado, p. 179, cogitando justamente de contrato relativo a várias edições:

"As obrigações do editor têm a mesma extensão e a mesma medida que seus direitos. A solução contrária colocaria o autor completamente à mercê do editor; ela seria sobretudo injusta, quando o autor estipulou um tanto por cento sôbre a venda, ou não cedeu ao editor senão um número limitado de edições. A inação fraudulenta do editor privaria o autor, no primeiro caso, de benefícios legítimos; ela o impediria, no segundo caso, de tratar com um outro editor." 
Coincide Alfredo de Gregorio, p. 271:

"Dalla estensione del diritto di edizione concesso all'editore risultano anzitutto i limiti entro i quali deve mantenersi quest'ultimo nella tiratura delle copie, la quale deve rispondere a ciò ch'è stato voluto esplicitamente od implicitamente delle parti."

Respondendo à terceira interrogação, as conseqüências que poderão advir ao primeiro editor, pela eventual ultrapassagem do número de exemplares indicados na notificação, são as já apontadas de ordem penal e de ordem civil.

Não é tão sem importância como poderia parecer à primeira vista a rescisão de um contrato que está no lusco-fusco de seu ocaso.

O cumprimento correto das obrigações de cada um dos contratantes levará ao esgotamento gradual e normal dos exemplares remanescentes, sem que um tenha qualquer motivo de reclamação do outro.

O cumprimento incorreto dará margem, com a rescisão, a tôdas as conseqüências e sequelas que a lei autoriza.

A primeira já se verificou, em virtude das violações do empresário: a resilição do contrato no que diz respeito à possibilidade de prosseguir nas edições não expressamente ressalvadas.

A segunda poderá ser a obrigação de indenizar as perdas e danos objetivando a reintegração ao patrimônio do autor do prejuízo decorrente da atitude injusta ou eventualmente fraudulenta de quem publica uma obra sem a necessária autorização.

É a hipótese de ter sido o contrato rescindido por culpa do editor, expressamente prevista pelos arts. 672 do Código Civil, $4 .^{\circ}$, parágrafo único do decreto n. 4.790 , de 2 de janeiro de 1924, pelos arts. 15 e 16 da Convenção de Berna, pelo art. 13 da Convenção Interamericana. 
A terceira será a busca e apreensão, e a quarta a adjudicação à parte lesada dos exemplares da reprodução fraudulenta, nos têrmos do art. 669 do Código Civil.

J. Labaurie vê, a pág. 143 , na medida, o meio de impedir a continuação do delito: "Elle a pour but de punir le contrefacteur et aussi d'jndemniser l'auteur lésé, à qui il est fait attribution du produit de la confiscation. Elle a donc un double caractère; elle est à la fois une peine et une réparation civile."

Acrescenta, na página seguinte, que ela pode ser decretada mesmo no caso de pagamento, sem prejuízo das mais amplas perdas e danos. Considera uma indenização pelo prejuízo sofrido pelo autor, conforme à eqüidade, não contrária nem ao texto nem ao espírito da lei, colocando em harmonia a legislação da contrafação artística e a da contrafação industrial.

Cumpre ter bem presente que não apenas o editor é chamado à responsabilidade: com êle, também solidáriamente, quem vender ou expuser à venda a obra impressa com fraude, nos têrmos do art. 670 do Código Civil.

$\mathrm{O}$ quarto quesito já está implìcitamente respondido. A situação que se apresenta é justamente a inversa: não existe qualquer possibilidade de obter o primeiro editor uma medida, como a de busca e apreensão dos volumes impressos por terceiro, ou de obrigar o segundo editor a comprar os exemplares remanescentes das edições anteriores. Êle é que corre o risco, se persistir na sua atitude negativa, de ver apreendidos os exemplares tardia ou irregularmente produzidos.

Finalmente, quanto à última pergunta: será medida de cautela exija o autor a prestação de contas a que tem direito, por via judicial. Elucidará, uma vez por tôdas, as relações com o primeiro editor, pondo têrmo à situação de incerteza por êste provocada com o seu silêncio, mesmo porque a remuneração do autor, como acentua Clóvis BeviláQua, depende do êxito da venda. 
A perícia contábil revelará a realização ou não das duas últimas edições a que tinha direito o I.B.E.P.

Mas se fôr apurado que as duas últimas edições não foram promovidas em tempo oportuno, deverá ser notificado o primeiro editor a que não mais as inicie se, a juízo do autor, as modificações que se façam necessárias tornem a publicação incompatível com as novas necessidades do ensino.

Rescindido, como está, de pleno direito o primeiro contrato, está o segundo editor em condições de promover o lançamento pelas suas impressoras: as cautelas tomadas pelo autor afastam a eventualidade de ofensa aos direitos legítimos do primeiro editor.

São Paulo, 21 de novembro de 1969. 